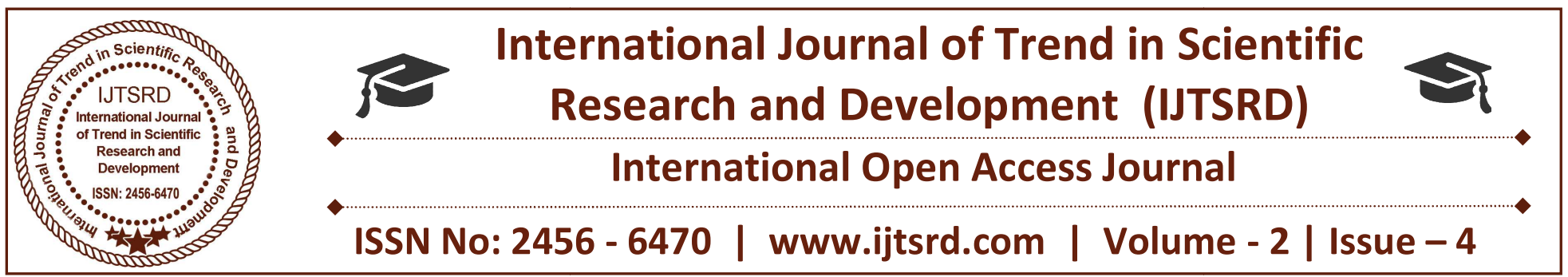

\title{
Social Media Marketing as a Competitive Strategy on Sales Performance in Small and Medium Enterprises in Nakuru Central Business District (CBD)- Kenya
}

\author{
Dr. Charles Mulandi Zakayo \\ Senior Lecturer, School of Business and Economics, \\ Kabarak University, Nakuru, Kenya
}

\section{ABSTRACT}

Social media offers new and innovative ways to small and medium business enterprises to communicate and network via the internet. Currently, there are various platforms provided by the social media networks such as Face-book, Google plus, LinkedIn, YouTube, Skype, WhatsApp and Twitter which are used as tools for marketing. Social media has opened a new perspective in the way business is conducted. The study sought to determine effects of social media marketing strategies on performance of small and medium enterprise in Nakuru Central Business District (CBD). The study was guided by the following objectives: To establish the social media strategies adopted by small and medium enterprises to enhance sales performance in Nakuru CBD, to explore the use of social media by small and medium enterprises in customer acquisition which leads to increased sales performance. The research adopted survey design. The study targeted the 350 registered micro and small enterprises in Nakuru CBD. The sample for the study was 78 micro and small enterprises. Simple random sampling procedure was used to select the small and medium Enterprises. Primary data was collected by the use of structured questionnaires. The findings indicated that marketing strategies and customer acquisition affect greatly and positively the sales performance among SMEs. The study recommends that online marketing strategies should be improved by SMEs in order to increase their sales performance and SMEs should have a clear customer acquisition framework in order to have a sustainable target market segment.
Keywords: Competitive strategies, Social Media Network Sites, Small and Medium Enterprises, Sales Performance, social media marketing

\section{INTRODUCTION}

\subsection{Background of the Study}

In a competitive business environment, organizations try to reach their customers in the best way possible. This requires the firms to develop strategies that will create customer satisfaction, value and loyalty (Bolton et al., 2014). With ever increasing usage of digital media by consumers and the tendency of more potential users joining the digital age, more companies are using digital marketing to reach their targeted markets. Indeed by the end of 2015, the number of Internet users around the world was over 3.2 billion and this vast information traffic will continue to double every year (Bosomworth, 2015). Social Media Marketing makes use of social media sites to raise visibility on the Internet and to promote products and services.

\subsection{Small and Medium Enterprises in Kenya}

According to the government of Kenya, firms are defined as small when they have between 11 and 50 employees and annual turnover does not exceed five million shillings while in medium enterprises employees range between 50 and 100 (GOK, 2012).

It is estimated that there are 7.5 million small and medium enterprises in Kenya, providing employment and income generation opportunities to low income sectors of the economy. This sector's contribution to 
the Gross Domestic Product (GDP) has increased from 13.8 percent in 1993 to about 40 percent in 2008. The small enterprise sector provided approximately $80 \%$ of total employment and contributed over $92 \%$ of the new jobs created in 2008 according to the Economic survey of 2014 (Mbugua,2016).

\subsection{Problem statement}

Small and medium enterprises, like any other organizations, are constantly faced with challenges in adapting to ever changing operational and technological conditions. For any organizations to survive, it is important to formulate, adopt and implement strategies that will make them competitive and continue to earn revenue and make profits. Creativity, innovation, as well as technological adoption can improve profit margins. Adoption of social media as a strategic marketing orientation can greatly enhance the profitability of micro and small enterprises. This study aimed at analyzing the effects of social media marketing strategies on sales performance of small and medium enterprises in Nakuru Central Business District (CBD).

\subsection{Objectives of the study}

$>$ To establish the social media strategies adopted by small and medium enterprises to enhance sales performance in Nakuru CBD.

$>$ To explore the use of social media marketing in customer acquisition that leads to increased sales performance.

\subsection{Scope}

The study focused on all the small and medium enterprises in Nakuru Central Business District (CBD).

\subsection{Definition of the terms}

Social Media: Social media are computer-mediated technologies that facilitate the creation and sharing of information, ideas, career interests and other forms of expression via virtual communities and networks (Dekker \& Engbersen, 2014).

Small and medium enterprises: in Kenya small enterprises have from 11 to 50 workers and medium enterprises have from 51 to 100 workers (Mwarari \& Ngugi, 2013).

\section{LITERATURE REVIEW}

2.1 Theoretical Basis of the Study

The study was based on two theories: social media theory and social media marketing theory.

\subsection{Social Media Theory}

According to Maravilhas (2014), scanning the business environment in terms of technology and market developments, spotting the opportunities for gaining advantage, identifying potential threats to current business and giving preference to transformational technologies are important in enabling success through technology. Chua \& Banerjee (2013), define social media as interactive Web 2.0 Internet-based applications. Organizations are actively leveraging the power of social networks to find new business opportunities (Venkatesh \& Jayasingh, 2016).

\subsection{Social Media Marketing Theory}

Social media marketing focuses on people, not products as the customers have the final say on how the product and services are offered. Marketers need to recognize the power and critical nature of the conversations being held by consumers using social media. social media marketing weapons can be used largely for free and easily in comparison with other promotional tools. This implies that social media is freely available in all internet based applications as long as you are connected to the internet.

\subsection{Social Media Strategies}

Social media has gained a lot of popularity over the past few years and companies are gradually shifting their advertising priorities to align better with today's buyers. Today's buyers are tech savvy (Odhiambo \& Adhiambo , 2012).

The most popular social network sites that are widely used today are: Face book, Twitter, YouTube and LinkedIn. In fact, Face-book, Twitter and YouTube are the most common channels that companies use in their online marketing for creating brand awareness to customers (Hansen et al. 2010).

\subsection{Face Book}

Face-book was launched in 2004 and had over 2 billion active users by 2017 of which, 350 million users access Face-book through mobile devices. An average Face-book user is estimated to have at least 130 friends and is connected to 80 community pages, 
groups and events. There are more than 70 languages available on the site. Its main use is to establish and maintain relationships in work related situations, in political affiliations or just among friends and families (Odhiambo \& Odhiambo, 2012). Face-book is today the most powerful tool for marketing. (Simon, 2011).

\subsection{Twitter}

Twitter was created in March 2006 by Jack Dorsey and launched the same year in July. Unlike Face-book where one can have friends to share different things, with twitter one has to get connected to the latest information on what they find interesting. One has to find the public stream that interests him and follow in the conversations. Each tweet is 140 characters in length. (O'Reilly, 2011). Twitter has helped Companies to position their brands and boost their market intelligence (Saravana \& Sugantha, 2012). largest professional network on the internet with more than 135 million members in over 200 countries and territories. In LinkedIn, companies have access to wealth information mostly provided through their profile data i.e. Company name, job title, and size of the company. LinkedIn uses this information for advertisements to targeted members. Companies pay some fees to advertise their products and services to particular LinkedIn members (Schaffer, 2013).

\subsection{Customer Acquisition}

Customer acquisition is always a starting point in building customer relationship. Many firms do not use appropriate criteria to identify and attract profitable customers and their marketing strategy is widely communicated to potential customers who may or may not be profitable (Linoff \& Berr, 2011). Social customer acquisition is essentially the art of building and maintaining relationships.

\subsection{LinkedIn}

LinkedIn started in 2002, but was officially launched on $5^{\text {th }}$ May, 2003. The company operates the world's

\subsection{Conceptual Framework}

\section{Independent Variables}

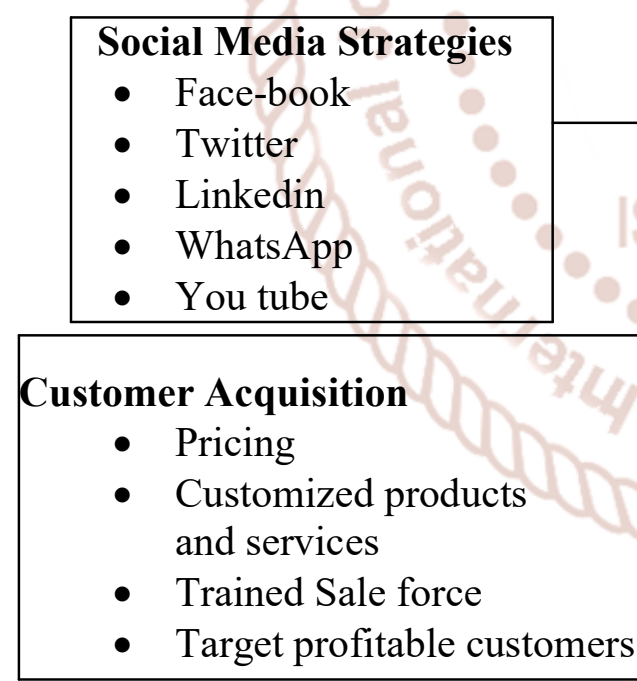

Source: Researcher 2018

\section{Dependant variables}

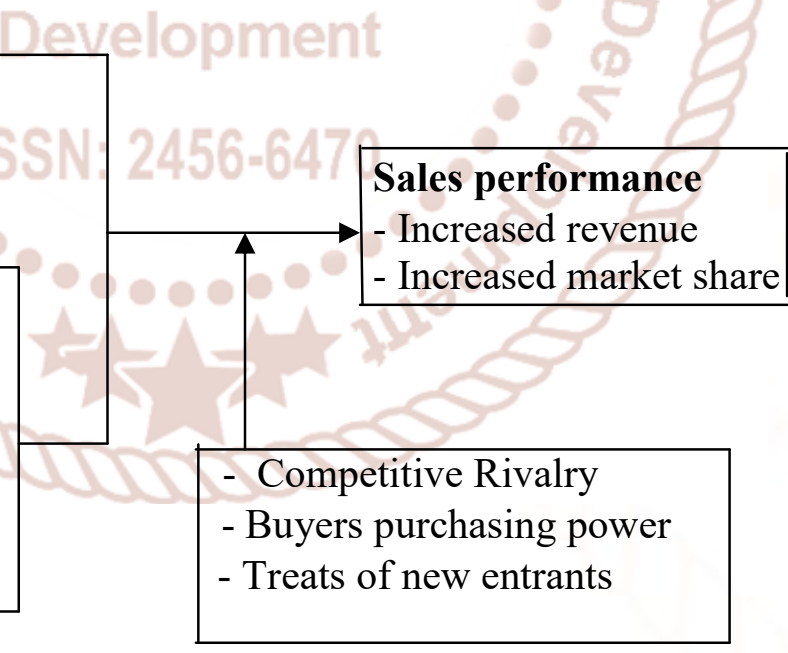

Moderating variables

\section{RESEARCH METHODOLOGY}

The study adopted both descriptive and correlation research design and targeted 350 small and medium enterprises registered in Nakuru CBD. The sample of 78 respondents was arrived at using Nassiuma's (2000) formula:-

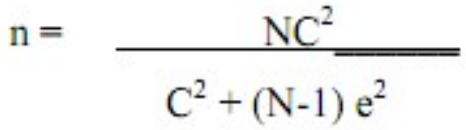

Where; $\mathrm{n}$, is the sample size being determined; $\mathrm{N}$, is the total population of the registered small and medium enterprises $\mathrm{C}$, is the coefficient of variation, 
$30 \%$ is usually acceptable (Nassiuma, 2000); e, is the relative standard error, $5 \%$ is acceptable.

$$
\begin{gathered}
\mathrm{n}=\frac{350 \times 0.3^{2}}{0.3^{2}+(350-1) 0.03^{2}} \\
\mathrm{n}=\frac{31.5}{0.09+0.1396} \\
\mathrm{n}=\frac{31.5}{0.2296} \\
=77.55 \approx 78 \text { enterprises }
\end{gathered}
$$

Questionnaires were used for data collection after they were validated and their reliability test at cronbach alpha value $0.7 \mathrm{~S}$

\subsection{Data analysis}

Statistical Package for Social Sciences was used in data processing. Data was descriptively analyzed and Pearson's Correlation ran to determine the relationship between Social media as a marketing strategy and sale performance in SMEs.

\subsection{Data Analysis, Interpretation And Discussion

\begin{tabular}{|c|c|c|c|c|c|c|c|}
\hline \multicolumn{2}{|c|}{ Frequency of Usage of Social Network } & \multicolumn{5}{|c|}{ Number of clients } & \multirow[t]{2}{*}{ Total } \\
\hline & & $\begin{array}{l}\text { Upto } \\
50 \\
\text { clients }\end{array}$ & $\begin{array}{c}51- \\
200 \\
\text { clients }\end{array}$ & $\begin{array}{c}201- \\
500 \\
\text { clients }\end{array}$ & $\begin{array}{l}\text { More } \\
\text { than } \\
500 \\
\text { clients }\end{array}$ & 5.00 & \\
\hline \multirow{4}{*}{ Facebook } & Count & 7 & 11 & 6 & 1 & 1 & 26 \\
\hline & Expected Count & 4.0 & 10.3 & 5.1 & 5.9 & .7 & 26.0 \\
\hline & $\%$ of Total & $9.9 \%$ & $15.5 \%$ & $8.5 \%$ & $1.4 \%$ & $1.4 \%$ & $36.6 \%$ \\
\hline & Count & 0 & 5 & 0 & 1 & 0 & 6 \\
\hline \multirow[t]{3}{*}{ Twitter } & Expected Count & .9 & 2.4 & 1.2 & 1.4 & .2 & 6.0 \\
\hline & $\%$ of Total & $0.0 \%$ & $7.0 \%$ & $0.0 \%$ & $1.4 \%$ & $0.0 \%$ & $8.5 \%$ \\
\hline & Count & 4 & 11 & 7 & 14 & 0 & 36 \\
\hline \multirow[t]{2}{*}{ Whatsapp } & Expected Count & 5.6 & 14.2 & 7.1 & 8.1 & 1.0 & 36.0 \\
\hline & $\%$ of Total & $5.6 \%$ & $15.5 \%$ & $9.9 \%$ & $19.7 \%$ & $0.0 \%$ & $50.7 \%$ \\
\hline & Count & 0 & 1 & 1 & 0 & 1 & 3 \\
\hline \multirow[t]{5}{*}{ Linkedin } & Expected Count & .5 & 1.2 & .6 & .7 & .1 & 3.0 \\
\hline & $\%$ of Total & $0.0 \%$ & $1.4 \%$ & $1.4 \%$ & $0.0 \%$ & $1.4 \%$ & $4.2 \%$ \\
\hline & Count & 11 & 28 & 14 & 16 & 2 & 71 \\
\hline & Expected Count & 11.0 & 28.0 & 14.0 & 16.0 & 2.0 & 71.0 \\
\hline & $\%$ of Total & $15.5 \%$ & $39.4 \%$ & $19.7 \%$ & $22.5 \%$ & $2.8 \%$ & $100.0 \%$ \\
\hline
\end{tabular} Response Rate}

Response rate was $71 \%$.

Frequency of Usage of Social Network and Number of Clients communicated to per week - Cross

\begin{tabular}{ll} 
Pearson Chi-Square & 29.65 \\
Df & 12 \\
p- value & .003 \\
\hline
\end{tabular}

It was noted that frequency of usage of social network and number of clients are statistically significant at 95\% confidence level (Pearson chi-square=29.65; $\mathrm{p}<0.05)$. This implies that there exists a significant association between Frequency of usage of Social Network and number of clients attracted to the business.

\subsection{Social media Marketing Strategies}

$87.3 \%$ of the respondents indicated that their organizations have incorporated social media marketing strategies $\left(\chi^{2}=72.16 ; \mathrm{p}<0.05\right) .91 .6 \%$ of the respondents agreed that social media strategy implementation is important for their firms and has 
positive impact on sales $\left(\chi^{2}=72.83 ; \mathrm{p}<0.05\right)$. This finding is consistent with Hidayat (2012) who assert that social media correlates with the organizational performance. In addition, nearly $71.8 \%$ of the respondents $\left(\chi^{2}=65.83 ; \mathrm{p}<0.05\right)$ agreed that their organizations spend more than 5 hours per week on social media marketing. $87.3 \%$ agreed that there was budget allocated for development of social media in their organizations. This implies that social media is given importance in these SMEs and has impacted on sales performance.

\subsection{Extent of Utilization of Social Media in customer acquisition}

\begin{tabular}{lrrrrrrrc}
\hline Social media & N & Never & Rarely & $\begin{array}{c}\text { Sometime } \\
\text { s }\end{array}$ & Often & Always & $\chi^{\mathbf{2}} \begin{array}{c}\boldsymbol{P} \text { - } \\
\text { value }\end{array}$ \\
\hline Linked in & & 9 & 2 & 15 & 27 & 18 & 24.99 & 0.000 \\
& 71 & $12.7 \%$ & $2.8 \%$ & $21.1 \%$ & $38.0 \%$ & $25.4 \%$ & & \\
Instagram & & 1 & 10 & 15 & 30 & 15 & 31.18 & 0.000 \\
& 71 & $1.4 \%$ & $14.1 \%$ & $21.1 \%$ & $42.3 \%$ & $21.1 \%$ & & \\
Face book & & 3 & 2 & 14 & 24 & 28 & 39.49 & 0.000 \\
& 71 & $4.2 \%$ & $2.8 \%$ & $19.7 \%$ & $33.8 \%$ & $39.4 \%$ & & \\
Whatsapp & & 1 & 2 & 10 & 32 & 26 & 56.11 & 0.000 \\
\multirow{2}{*}{ Twitter } & 71 & $1.4 \%$ & $2.8 \%$ & $14.1 \%$ & $45.1 \%$ & $36.6 \%$ & & \\
& 71 & 5 & 4 & 14 & 33 & 15 & 38.23 & 0.000 \\
& $7.0 \%$ & $5.6 \%$ & $19.7 \%$ & $46.5 \%$ & $21.1 \%$ & & \\
\hline
\end{tabular}

$73.2 \%$ of the respondents $\left(\chi^{2}=39.49 ; \mathrm{p}<0.05\right)$ affirmed that face-book is often used in customer acquisition, $81.7 \%$ of respondents $\left(\chi^{2}=56.11: \mathrm{p}<0.05\right)$ affirmed that Whatsapp is more often used in customer acquisition, $63.4 \%$ of respondent $\left(\chi^{2}=31.18 ; p<0.05\right)$ affirmed that Instagram is often used in customer acquisition, $67.6 \%$ of respondents $\left(\chi^{2}=38.23 ; p<0.05\right)$ affirmed that Twitter is often used in customer acquisition and $63.4 \%$ of respondents $\left(\chi^{2}=24.99 ; \mathrm{p}<0.05\right)$ affirmed that Linkedin is used in customer acquisition.

\subsection{Sales Performance}

The findings revealed that $81.7 \%$ of respondents $\left(\chi^{2}=43.54 ; p<0.05\right)$ acknowledged that social media enables the firm to customize promotion to target specific groups. This view was supported by $76.1 \%$ of respondents $\left(\chi^{2}=52.73 ; \mathrm{p}<0.05\right)$ who admitted that Social media is more efficient and cost-effective than other marketing outreach and is in line with the findings of Berthon et al (2012) that social media enables customers and employees to share experiences and help companies to get more networked. This increases performance and service delivery, thus enabling efficient achievement of corporate goals and objectives.
3.6 Correlation between Sales Performance, Social Media Marketing Strategies, and Customer Acquisition adopted by SMEs

An analysis was conducted to investigate the relationship between Sales Performance and Social Media Marketing Strategies adopted by SMEs. The results indicated that there exist a positive and statistically significant relationship between Sales Performance and Social Media Marketing Strategies $\left(\mathrm{r}=0.354^{* *} ; p<0.01\right)$. This implies that implementation of social Media Marketing Strategies increases sales Performance of the organization. Furthermore, an analysis was conducted to determine the relationship between sales performance and customer acquisition. It was noted that there exist a positive and statistically significant relationship between sales performance and customer acquisition $\left(\mathrm{r}=0.728^{* *} ; \mathrm{p}<0.01\right)$. This implies that when customer acquisition is improved, sales performance improves as well. Therefore social media provides more effective platforms to new products thus increasing sales performance of an organization.

\subsection{Regression Analysis}

Regression analysis was conducted to examine the effect of social media marketing as a competitive strategy on sales performance in Small and Medium Enterprise in Nakuru (CBD). The independent 
International Journal of Trend in Scientific Research and Development (IJTSRD) ISSN: 2456-6470

variables for the study included social media Dependent Variable was Sales Performance. marketing strategies and customer acquisition while

Model Summary

\begin{tabular}{lcccc}
\hline Model & $\mathrm{R}$ & R Square & $\begin{array}{c}\text { Adjusted R } \\
\text { Square }\end{array}$ & $\begin{array}{c}\text { Std. Error of the } \\
\text { Estimate }\end{array}$ \\
\hline 1 & .843 & .710 & .688 & 0.24401
\end{tabular}

a. Dependent Variable: Sales Performance

b. Predictors: (Constant), Social Media Marketing Strategies, Customer Acquisition,

Model summary shows Adjusted R Square value as 0.688. This means $68.8 \%$ variation in sales performance. It explains the variation of independent variables which include Social Media Marketing Strategies and Customer Acquisition with a standard error of 0.244 . The unexplained variation is $31.2 \%$ which could be explained by other factors outside the study variables.

\subsection{ANOVA Analysis}

F-statistics were computed to find out the overall strength of the model.

\begin{tabular}{|c|c|c|c|c|c|c|}
\hline Model & & Sum of & $\mathrm{df}$ & Mean Square & $\mathrm{F}$ & Sig. \\
\hline \multirow{3}{*}{1} & Regression & 9.476 & 5 & 1.895 & 31.829 & $.000^{\mathrm{b}}$ \\
\hline & Residual & 3.870 & 65 & .060 & & \\
\hline & Total & 13.346 & 70 & & & \\
\hline
\end{tabular}

The findings revealed value of F-Statistic $31.829<0.05$. Therefore the model is $95 \%$ efficient in which indicates that the model is significant at $95 \%$ predicting the effect of independent variables on confidence level; $\mathrm{R}^{2}=0.657, \mathrm{~F}(5,65)=31.829 ; p \quad$ dependent variable.

\subsection{COEFFICIENTS}

\begin{tabular}{|c|c|c|c|c|c|c|c|}
\hline \multirow[t]{2}{*}{ Model } & \multicolumn{2}{|c|}{$\begin{array}{l}\text { Un-standardized } \\
\text { Coefficients }\end{array}$} & \multirow{2}{*}{$\begin{array}{l}\text { Standardized Coefficients } \\
\text { Beta }\end{array}$} & \multirow[t]{2}{*}{$\mathrm{T}$} & \multirow[t]{2}{*}{ Sig. } & \multicolumn{2}{|c|}{$\begin{array}{l}\text { Collinearity } \\
\text { Statistics }\end{array}$} \\
\hline & B & $\begin{array}{l}\text { Std. } \\
\text { Error }\end{array}$ & & & & Tolerance & VIF \\
\hline (Constant) & .030 & .335 & & .088 & .930 & & \\
\hline $\begin{array}{l}\text { Social Media } \\
\text { Marketing } \\
\text { Strategies }\end{array}$ & .108 & .069 & .116 & 1.567 & .122 & .814 & 1.229 \\
\hline $\begin{array}{l}\text { Customer } \\
\text { Acquisition }\end{array}$ & .509 & .084 & 487 & 6.068 & .000 & .692 & 1.446 \\
\hline
\end{tabular}

a. Dependent Variable: Sales Performance

b. Predictors: (Constant) Social Media Marketing Strategies and, Customer Acquisition 
Collinearity Statistics was computed to investigate inter-associations among the independent variables. The VIF value which was obtained remained 1.229 and 1.446 signifying that the VIF value stood between the acceptable range of 1 to 10 . It can be concluded that there is no multi collinearity symptoms in the model.

\section{CONCLUSSIONS AND RECOMMENDATION}

\subsection{Conclusion}

It can be concluded that marketing strategies and customer acquisition affect up to $64.3 \%$ positive variation in sales performance among SMEs.

\subsection{Recommendation}

The study recommends that

Online marketing strategies should be improved by SMEs in order to increase their sales performance.

$>$ SMEs should have a clear customer acquisition framework in order to have a sustainable target market segments.

\section{REFERENCES}

1. Berthon, P. R., Pitt, L. F., Plangger, K., \& Shapiro, D. (2012). Marketing meets Web 2.0, social media, and creative consumers: Implications for international marketing strategy. Business horizons, 55(3), 261-271.

2. Bolton, R., Gustafsson, A., McColl-Kennedy, J., J. Sirianni, N., \& K. Tse, D. (2014). Small details that make big differences: a radical approach to consumption experience as a firm's differentiating strategy. Journal of Service Management, 25(2), 253-274.

3. Bosomworth, D. (2015). Mobile marketing statistics 2015. Leeds: Smart Insights (Marketing Intelligence) Ltd.

4. Chua, A. Y., \& Banerjee, S. (2013). Customer knowledge management via social media: the case of Starbucks. Journal of Knowledge Management, 17(2), 237-249.

5. Dekker, R., \& Engbersen, G. (2014). How social media transform migrant networks and facilitate migration. Global Networks, 14(4), 401-418.

6. Gerhardt, D. R. (2012). Social media amplify consumer investment in trademarks.

7. GOK (2012). The Micro and Small Enterprises Act 2012. Kenya Gazette Supplement No. 219
(Acts No.55). Nairobi, Government printer, Government of Kenya.

8. Hansen, D., Shneiderman, B., \& Smith, M. A. (2010). Analyzing social media networks with NodeXL: Insights from a connected world. Morgan Kaufmann.

9. Hidayat, C. (2012). Social Media Marketing Model.

10. Linoff, G. S., \& Berry, M. J. (2011). Data mining techniques: for marketing, sales, and customer relationship management. John Wiley \& Sons.

11. Maravilhas, S. (2014). Social media tools for quality business information. In Information Quality and Governance for Business Intelligence (pp. 167-193). IGI Global.

12. Mbugua, F. (2016). Effects of county government policies on the performance of small and medium enterprise in Kenya: a case of Kiambu County. Strategic Journal of Business \& Change Management, 3(2).

13. Mwarari, M. M., \& Ngugi, P. K. (2013). Factors influencing listing of Kenyan SMEs in the securities market for capital raising opportunities. European journal of management sciences and economics, 1(2), 99-115.

14. Nassiuma, D. (2000) Survey Sampling: Theory and Methods, University of Nairobi Press, Nairobi.

15. Odhiambo, M., \&Adhiambo, C. (2012). Social Media as a Tool of Marketing and Creating Brand awareness: Case study research.

16. O'Reilly, T., \& Milstein, S. (2011). The twitter book. " O'Reilly Media, Inc.".

17. Sarava. M. \& Sugantha, T. (2012). Social media marketing. Life Science Journal, 9(4), 4444-4451.

18. Schaffer, N. (2013). Maximizing Linkedin for Sales and Social Media Marketing: An Unofficial, Practical Guide to Selling and Developing B2B Business on Linkedin. Neal Schaffer.

19. Simon, P. (2011). The age of the platform: How Amazon, Apple, Facebook, and Google have redefined business. Book Baby.

20. Venkatesh, R., \& Jayasingh, S. (2016). Transformation of Business through Social Media. Social Media Listening and Monitoring for Business Applications. 